\title{
ストロンチウム・マンガン複酸化物の合 成*1
}

(昭 和 44 年 9 月 12 日受理)

水谷惟恭・北沢章生・大隈信行・加藤誠 軌*2

マンガンとストロンチウムとからなる数種類の新しい複酸化物を合成し, それぞれの最適合成条件, 性状, 結晶構造およびそれ

ら相互の相関関係を明らかにした。

それぞれの混合比の反応体を空気中で $1200^{\circ} \mathrm{C}$ 以下の比較的低温度に加熱すると $\alpha-\mathrm{SrMnO}_{3}$ (六方晶系, 高温型 $\mathrm{BaMnO}_{3}$ と同 形の $\left.a_{0}=5.447 \pm 0.001 \AA, c_{0}=9.081 \pm 0.002 \AA\right), \alpha-\mathrm{Sr}_{2} \mathrm{MnO}_{4}$ 扰よび $\mathrm{SrMn}_{3} \mathrm{O}_{x}(x=5.6 \sim 6.0)$ が得られる。

さらに高温度では $\beta-\mathrm{SrMnO}_{3}$ (立方晶系ぺロブスカイト構造, $a_{0}=3.8057 \pm 0.0003 \AA$ )， $\beta-\mathrm{Sr}_{2} \mathrm{MnO}_{4}$ (正方晶系， $\mathrm{K}_{2} \mathrm{NiF}_{4}$ と同 形, $a_{0}=3.787 \pm 0.001 \AA, c_{0}=12.495 \pm 0.005 \AA$ ) 打よび $\mathrm{Sr}_{3} \mathrm{Mn}_{2} \mathrm{O}_{7}$ (正方晶系, $\mathrm{Sr}_{3} \mathrm{Ti}_{2} \mathrm{O}_{7}$ と同形, $a_{0}=3.801 \pm 0.001 \AA, c_{0}=20.06$ $\pm 0.001 \AA)$ が生成するが, $\beta-\mathrm{SrMnO}_{3}$ は急冷しないと, $\alpha-\mathrm{SrMnO}_{3}$ に転移する。一方, $1400 \sim 1500^{\circ} \mathrm{C}$ の狭い温度域で $\mathrm{Sr}_{4} \mathrm{Mn}_{3} \mathrm{O}_{10}$ が生成する。これらの生成物のうち， $\alpha-\mathrm{Sr}_{2} \mathrm{MnO}_{4}, \mathrm{SrMn}_{3} \mathrm{O}_{x}(x=5.6 \sim 6.0), \beta-\mathrm{S}_{\mathrm{N}} \mathrm{MnO}_{3}, \mathrm{Sr}_{3} \mathrm{Mn}_{2} \mathrm{O}_{7}, \mathrm{Sr}_{4} \mathrm{Mn}_{3} \mathrm{O}_{10}$ は従来まったく 知られていない化合物である。

反応体を窒素中で加熱するといずれの混合比でも $\beta-\mathrm{Sr}_{2} \mathrm{MnO}_{4}$ が優先的にしかも空気中に扣けるよりも著しく低い程度で生成す る。炭酸がス中で加熱すると $\beta-\mathrm{SrMnO}_{3}$ が同様に優先的に生成する。

さらに各複酸化物の結晶構造の相関関係についても検討した。 $\beta-\mathrm{Sr}_{2} \mathrm{MnO}_{4}$ はペロブスカイト構造である $\beta-\mathrm{SrMnO}_{3}$ の一単位 毎に一層の $\mathrm{SrO}$ が挿入された構造であり, $\mathrm{Sr}_{3} \mathrm{Mn}_{2} \mathrm{O}_{7}$ は $\beta-\mathrm{SrMnO}_{3}$ の二単位毎に一層の $\mathrm{SrO}$ がはさまれた構造である。

\section{1 緒 言}

種々の原子価をとりらる元素を含む化合物は, それが置かれて いる雲囲気や製造時の雲囲気に著しく影響されることは広く知ら れていることである。たとえば工業的にフェライトを製造する際 には鉄, マンガン, 銅などの原子価を制御するために焼成時や冷 却時の酸素分圧を厳密に管理する必要がある。マンガンは多数の 原子価をとり得るため，これを含む複酸化物の研究には雾囲気の 制御は欠くことができない技術である。

著者らは現在マンガンとアルカリ土類金属との複酸化物に関す る系統的な研究を行なっているが，本報ではストロンチウムーマ ンガン-酸素系のペロブスカイト構造を基本とする一連の新しい 複酸化物について述べる。

マンガンとストロンチウムとの複酸化物について以下に紹介す るいくつかの研究がある。

Scholder ${ }^{1)}$ は $\mathrm{Sr}_{2} \mathrm{MnO}_{4}$ が $\mathrm{K}_{2} \mathrm{NiF}_{4}$ と同一の構造であることを 指摘している。さらに, 種々の元素の +5 価の酸素酸塩に関す る彼の総説 ${ }^{2}$ のなかで $\mathrm{Sr}_{3}\left(\mathrm{MnO}_{2}\right)_{2}$ についてもられている。これ によると, $\mathrm{Sr}_{2}\left[\mathrm{Mn}(\mathrm{OH})_{6}\right]$ を酸素中で $250 \sim 350^{\circ} \mathrm{C}$ に加熱するこ とによって青緑色の $\mathrm{Sr}_{3}\left(\mathrm{MnO}_{2}\right)_{2}$ が得られ, その際に遊離した $\mathrm{Sr}(\mathrm{OH})_{2}$ は沸騰したメタノールまたは $2 \% \mathrm{Sr}(\mathrm{OH})_{2}$ 溶液によっ て取り除くことができる。

また, Klemm の総説 ${ }^{3)}$ のなかにリンカイ石構造の $\mathrm{Sr}_{5}\left(\mathrm{MnO}_{4}\right)_{2}$ . $\mathrm{OH}$ なる化合物 (六方晶系, $a_{0}=9.94 \AA, c_{0}=7.42 \AA, c_{0} / a_{0}=$ 0.747) が記載されているが詳細は不明である。

Baltz と Plieth ${ }^{4}$ は単結晶を用いて $\mathrm{K}_{2} \mathrm{NiF}_{4}$ の構造解析を行 なったが，そのなかで $\mathrm{Sr}_{2} \mathrm{MoO}_{4}$ や $\mathrm{Sr}_{2} \mathrm{TiO}_{4}$ とともに $\mathrm{Sr}_{2} \mathrm{MnO}_{4}$

$*_{1}$ この報文を「マンガンの複酸化物に関する研究（第 1 報）」 とする.

*2 Nobuyasu Mizutani, Akio Kitazawa, Nobuyuki ŌKUMA, Masanori KATO 東京工業大学工学部無機材料 工学科：東京都目黒区大岡山.

1) R, Scholder, Z. Elektrochem., 56, 879 (1952).

2) R. Scholder, Angew. Chem., 66, 461 (1954).

3) W. Klemm, Angew. Chem., 66, 468 (1954).

4) D. Baltz, K. Plieth, Z. Elektrochem., 59, 545 (1955).
が同じ構造を持ち，その格子定数が $a_{0}=3.79 \AA ， c_{0}=12.43 \AA$, $c_{0} / a_{0}=3.28$ であることと, $\mathrm{SrMoO}_{3}$ や $\mathrm{SrTiO}_{3}$ はペロブスカイ 卜構造をとるが, $\mathrm{SrMnO}_{3}$ が存在するかどうか不明であると述べ ている。その他, ( $\mathrm{Sr}, \mathrm{La}) \mathrm{MnO}_{3}$ の磁性に関する研究5) がある。

ごく最近, Syono ら 合物についての研究が報告されたが，このなかで $\mathrm{SrMnO}_{3}$ には 二つの種類のあることが述べられている。 $\mathrm{SrMnO}_{3}$ ( I ) は炭酸ス トロンチウムと二酸化マンガンの等モル混合物を空気中で 1350 ${ }^{\circ} \mathrm{C}$ に 20 時間以上加熱した後ゆっくり冷却することによって得 られ, $\mathrm{Hardy}^{7)}$ が解析した高温型 $\mathrm{BaMnO}_{3}$ と同じ結晶構造に 属する。この化合物を $50 \mathrm{~kb}$ の圧力下, $850 \sim 1300^{\circ} \mathrm{C}$ に加熱す ると $\mathrm{SrMnO}_{3}$ (II) に転移する。その結晶構造は $\mathrm{BaTiO}_{3}$ の高温 相 (六方晶系) と同形で格子定数は $a_{0}=5.431 \pm 0.001 \AA ， c_{0}=$ 13. $396 \pm 0.005 \AA ， \quad c_{0} / a_{0}=2.467 \pm 0.002$ である。またこの報文の なかで, 立方晶系ペロブスカイト型の $\mathrm{SrMnO}_{3}$ は少なくとも 100 $\mathrm{kb}$ 以上の高圧下でなければ生成しないであろうと推定している。

次に本実験に関係のあるマンガン酸化物と炭酸ストロンチウム とについて概略を述べる。マンガンには $+2, \quad+3,+4,+5$, $+6,+7$ の原子価があり, これらに相当する酸化物には $\mathrm{MnO}$, $\mathrm{Mn}_{2} \mathrm{O}_{3}, \mathrm{MnO}_{2}$ および $\mathrm{Mn}_{2} \mathrm{O}_{7}$ がある。 $\mathrm{MnO}$ は食塩構造, $\mathrm{Mn}_{2} \mathrm{O}_{3}$ は酸化スカンジウム構造を持ち, $\mathrm{MnO}_{2}$ には少なくとも 4 種以上 の変態があり, 結晶水を持っているものの構造はさらに複雑であ る8)。このほかに混合原子価の $\mathrm{Mn}_{3} \mathrm{O}_{4}$ がありこれには 2 種の変 態 (立方晶および正方晶系) がある ${ }^{9)}+5$ 価の酸化物は知られて おらず, $\mathrm{MnO}_{3}$ が存在するかどうかも明らかではない10)。 $\mathrm{Mn}_{2} \mathrm{O}_{7}$ は特有の臭いを持つ不安定な油状の液体で, $55^{\circ} \mathrm{C}$ 付近から分解 乙始め $95^{\circ} \mathrm{C}$ で爆発するので空気を断って $-10^{\circ} \mathrm{C}$ 以下に保存す

5) G. Matsumoto, S. Iida, J. Phys. Soc. Japan, 21, 2734 (1966).

6) Y.Syono, S.Akimoto, J. Phys. Soc. Japan, 26, 993 (1969).

7) A. Hardy, Acta. Cryst., 15, 179 (1962).

8) O. Bricker, Am. Mineral., 50, 1296 (1965).

9) N. G. Schmahl, B.Stemmler, J. Electrochem. Soc., 112, 365 (1965)

10）千谷利三, “無機化学 (下)”, 産業図書 (1960) p. 1050. 
る必要がある11)。結局, 室温で安定なものは +4 価以下の酸化 物に限られる。

一方，Mn-O 系の平衡については Muan ら ${ }^{12)}$ の詳細な研究が 专る。空気中で $\mathrm{MnO}_{2}$ を加熱すると $400 \sim 500^{\circ} \mathrm{C}$ で $\mathrm{Mn}_{2} \mathrm{O}_{3}$ に, $900^{\circ} \mathrm{C}$ 付近で $\mathrm{Mn}_{3} \mathrm{O}_{4}$ になり, $1200^{\circ} \mathrm{C}$ 以上の高温では $\mathrm{MnO}$ に なる。これらの反応の逆反応は $\mathrm{Mn}_{2} \mathrm{O}_{3}$ の $\mathrm{MnO}_{2}$ への酸化反応以 外は, 比較的す及やかに進行する。Otto ${ }^{13)}$ によれば, $\mathrm{Mn}_{2} \mathrm{O}_{3}$ を 100 気圧以上の高酸素压下で $475^{\circ} \mathrm{C}$ に数干時間保持しても完全に は酸化されないという。

炭酸マンガンを加熱すると $300^{\circ} \mathrm{C}$ 付近から分解するが雾囲気に よって分解生成物が異なり, 不活性気体中では $\mathrm{MnO}$ に, 空気中 では $\mathrm{Mn}_{2} \mathrm{O}_{3}$ または $\mathrm{Mn}_{3} \mathrm{O}_{4}$ になることが多く，結晶水を持った $\mathrm{MnCO}_{3} \cdot \mathrm{H}_{2} \mathrm{O}$ では分解条件によっては $\mathrm{MnO}_{1.9}$ 程度までになると されている(14)。 $\mathrm{MnO}$ の融点は $1650^{\circ} \mathrm{C}$ である。

炭酸ストロンチウムは空気中では $900^{\circ} \mathrm{C}$ 以上に加熱すると分解 して酸化ストロンチウム, SrO になる。 SrO は吸湿, 吸炭酸作 用が著しく強く, 空気中では安定には存在できない。融点は 2200 ${ }^{\circ} \mathrm{C}$ である。

\section{2 実 験 方 法}

\section{$2 \cdot 1$ 試料の調製と加熱方法}

反応体としては炭酸ストロンチウム(小宗化学(株)製 試薬特 級，純度 $99 \%$ 以上）と炭酸マンガン (小宗化学(株)製 試薬特 級, 2.3 の分析方法によるマンガン含有量は $43.5 \%$ で炭酸マン ガンに換算すると $91.0 \%$ に相当する。不純物は大部分水分であ る）を使用した。反応体はそれぞれ所定のモル比（炭酸マンガン の純度を補正した）に科量したものをメノウ乳鉢を用いて手動で 30 分以上乾式混合した。これを約 $400 \mathrm{~kg} / \mathrm{cm}^{2}$ の圧力で厚さ 3 $\sim 4 \mathrm{~mm}$, 直径 $10 \mathrm{~mm}$ のペレットに成形した。ペレットは必要 に応じて $5 \mathrm{~mm}$ 角程度に砕いて加熱試料に供した。

反応体の熱処理には横形のカンタル管状炉またはシリコニット 管状炬と千野製作所製 E 580 型 PID 方式の温度調節計を使用 して試料の温度を $\pm 2{ }^{\circ} \mathrm{C}$ 以内に制御した。試料は白金 $-20 \%$ 口 ジウム板にのせて加熱し，急冷する際には炉中からすばやく冷熱 部に引き出し，必要な場合には水中に投下寸る方法を用いた。

$1500^{\circ} \mathrm{C}$ 以上の加熱には ZAT 炉（日本碍子（株）製ジルコニ ア抵抗炉)を使用した。この場合には加熱試料のペレットは 1000 $\sim 1200^{\circ} \mathrm{C}$ で 8 時間以上仮焼成した後粉砕し, 直径 $5 \mathrm{~mm}$, 厚さ $3 \mathrm{~mm}$ のペレットに成形する。このペレットを 2 枚重ねてジルコ ニア製の台にのせ，上段のペレットを測定に供した。な拉，下段 のペレットとジルコニア台との間の相互作用は注とんど認められ なかった。温度の測定には光温度計を使用し測温精度は $\pm 30^{\circ} \mathrm{C}$ 程度である。

雲囲父の制御には管状炉の一方から種々のガスを導入する方法 によった。流通速度は線速度約 $2 \mathrm{~cm} / \mathrm{sec}$ である。炭酸ガス, 窒 素ガスおよび酸素ガスは市販のボンベガスをシリカゲルと五酸化 リンの吸湿管を通して用いた。

11) 文献 10, p. 1043

12) W.C.Hahn, Jr., Arnulf Muan, Am. J. Sci., 258, 66 (1960).

13) E. M. Otto, J. Electrochem. Soc., 112, 367 (1965).

14）伊藤，高橋，工化，64，1543 (1961).

\section{$2 \cdot 2 \mathrm{X}$ 線分析}

$\mathrm{X}$ 線回折装置はフィリップス社製 $\mathrm{X}$ 線回折計 $\left(\mathrm{Cu} K_{\alpha}\right)$ を使用 し, 精密測定の際の測定条件はターゲット：Cu $K_{\alpha}$, フィルター： $\mathrm{Ni}$, 電圧 : $30 \mathrm{kV}$, 電流 : $20 \mathrm{~mA}$, 走查速度 : $1 / 4^{\circ} / \mathrm{min}$, 時定数 : 4, フルスケール : $400 \mathrm{cps}$ である。

\section{$2 \cdot 3$ 化学分析}

マンガンは種々の原子価をとり得るのでマンガン酸化物や生成 物であるストロンチウム・マンガン複酸化物中の各元素の正確な 含有量の分析が重要である。これらの化合物中の酸素含有量は值 接定量する有効な分析方法が知られていないので, 全マンガン量 と二酸化マンガン量とをそれぞれ以下に述べる分析法によって求 めこれから算出した。

全マンガン量の分析には藤原らの方法 ${ }^{15)}$ 用いた。これは過塩 素酸-リン酸混合液中ではマンガンがすべて $\mathrm{Mn}^{3+}$ イオンになる ことを利用するもので, 試料が溶解し難い場合には少量の過酸化 水素水を添加した。ついで濃度既知の $\mathrm{Fe}^{2+}$ 溶液 (モール塩) で 滴定してマンガンの定量を行なう。

他方, 二酸化マンガン量の分析にはモール塩法が最も信頼でき るとされているが，この方法では高温度で焼成した著者らの試料 はほとんど溶解せず利用できなかったので， Brist らがカルシウ ム・マンガン塩の分析に使用した方法 ${ }^{16)}$ 改良して用いた。これ は試料中の $\mathrm{Mn}^{4+}$ および $\mathrm{Mn}^{3+}$ イオンを $\mathrm{Mn}^{2+}$ イオンに還元す るのに要するシュウ酸ナトリウム量を過マンガン酸カリウム溶夜 で滴定して求める方法である。すなわち, $100 \mathrm{mg}$ 程度の試料を 三角フラスコにとり, 少量の蒸留水で試料を浸した後, $0.1 \mathrm{~N}$ シ ユウ酸ナトリウム標準液 $20 \mathrm{ml}$ を加光，さらに $70 \%$ 過酸化水 素水 $10 \mathrm{~m} l$ と蒸留水 $50 \mathrm{~m} l$ を添加する。空気によるシュウ酸ナ トリウムの分解を防ぐために炭酸ガスを三角フラスコに通じなが ら, 温水 $\left(70^{\circ} \mathrm{C}\right)$ で分解溶解させる。過剩のシュウ酸ナトリウム を $0.1 \mathrm{~N}$ 過マンガン酸ナトリウムで滴定してマンガンの 還元に 要したシュウ酸ナトリウム量を求めた。全マンガン量および二酸 化マンガン量の分析精度は $\pm 5 \%$ 以内である。

\section{3 実 験 結 果}

\section{$3 \cdot 1$ 低温型複酸化物}

種々の混合比の反応体を空気中で 800 $1200^{\circ} \mathrm{C} に$ 加熱したもの について，X線回折によって調べた結果を表 1 に示す。反応生成 物のX線回折図形は低温で焼成したものほど，またマンガン含有 量の多いものほど不鮮明であるが，表 1 から $\mathrm{Sr}: \mathrm{Mn}$ のモル比 が $1: 1,2: 1$ 拉よび $1: 3$ の三種類の化合物の存在が認められ る。 $2: 1$ および $1: 3$ の化合物は従来知られていない新しい化 合物である。

1:1 の化合物は黑色でやや青味がかっている。X 線回折図形 は Syono ら ${ }^{6}$ が報告している $\mathrm{SrMnO}_{3}$ (I) のそれとほぼ一致し， $\mathrm{Hardy}^{7}$ ) の解析した高温型 $\mathrm{BaMnO}_{3}{ }^{17}$ ) (六方晶系) と同じ構造 を持ち，その格子定数は $a_{0}=5.447 \pm 0.001 \AA ， c_{0}=9.081 \pm 0.002$ $\AA ， c_{0} / a_{0}=1.667 \pm 0.001$ である。この化合物は温水中に浸漬し てもX線回折図形や色調はまったく変化しない。本報ではこの化

15）長島, M. Codell, 藤原, 分析化学, 13, 261 (1964).

16) C. Brist, M. Lucco-Borlera, J. Inorg. Nucl. Chem., 27, 2129 (1965).

.17) ASTM カード, 14-228. 
合物を $\alpha-\mathrm{SrMnO}_{3}$ とよぶことにする。

$2: 1$ の化合物は黒っぽいうぐいす色 で，組成は $\mathrm{Sr}_{2} \mathrm{MnO}_{4}$ である。水分によ って分解する傾向があり結晶構造は不明 である。この化合物は後で述べるように さらに高い温度に加熱すると, 高温型の $\beta-\mathrm{Sr}_{2} \mathrm{MnO}_{4}$ に転移するから，本報では これを $\alpha-\mathrm{Sr}_{2} \mathrm{MnO}_{4}$ とよぶことにする。

.1:3の化合物は黑色ないし黒褐色で 前二者に比べて焼成物は，比較的硬く焼 結している。化学分析で求めた組成は,

$\mathrm{SrMn}_{3} \mathrm{O}_{5.6 \sim 6} 0^{* 1}$ で結晶構造は不明, 1400
表 1 低温型複酸化物の生成状沉

\begin{tabular}{|c|c|c|c|}
\hline $\mathrm{Sr}: \mathrm{Mn}$ & $800^{*}$ & 1000 & 1200 \\
\hline (モル此) & $16^{* *}$ & 10 & 10 \\
\hline $10: 1$ & $\alpha-\mathrm{Sr}_{2} \mathrm{MnO}_{4}, \mathrm{SrCO}_{3}$ & $\alpha-\mathrm{Sr}_{2} \mathrm{MnO}_{4}, \mathrm{SrO}$ & \\
\hline $6: 1$ & $\alpha-\mathrm{Sr}_{2} \mathrm{MnO}_{4}, \mathrm{SrCO}_{3}$ & $\alpha-\mathrm{Sr}_{2} \mathrm{MnO}_{4}, \mathrm{SrO}$ & \\
\hline $4: 1$ & $\alpha-\mathrm{Sr}_{2} \mathrm{MnO}_{4}, \mathrm{SrCO}_{3}$ & $\alpha-\mathrm{Sr}_{2} \mathrm{MnO}_{4}, \mathrm{SrO}$ & $\alpha-\mathrm{Sr}_{2} \mathrm{MnO}_{4}, \mathrm{SrO}$ \\
\hline $3: 1$ & $\alpha-\mathrm{Sr}_{2} \mathrm{MnO}_{4}, \mathrm{SrCO}_{3}$ & $\alpha-\mathrm{Sr}_{2} \mathrm{MnO}_{4}, \mathrm{SrO}$ & $\alpha-\mathrm{Sr}_{2} \mathrm{MnO}_{4}, \mathrm{SrO}$ \\
\hline $2: 1$ & $\alpha-\mathrm{Sr}_{2} \mathrm{MnO}_{4}$ & $\alpha-\mathrm{Sr}_{2} \mathrm{MnO}_{4}$ & $\alpha-\mathrm{Sr}_{2} \mathrm{MnO}_{4}$ \\
\hline $3: 2$ & $\alpha-\mathrm{SrMnO}_{3}, \alpha-\mathrm{Sr}_{2} \mathrm{MnO}_{4}$ & $\alpha-\mathrm{SrMnO}_{3}, \quad \alpha-\mathrm{Sr}_{2} \mathrm{MnO}_{4}$ & $\alpha-\mathrm{SrMnO}_{3}, \quad \alpha-\mathrm{Sr}_{2} \mathrm{MnO}_{4}$ \\
\hline $1: 1$ & $\alpha-\mathrm{SrMnO}_{3}$ & $\alpha-\mathrm{SrMnO}_{3}$ & $\alpha-\mathrm{SrMnO}_{3}$ \\
\hline $2: 3$ & $\alpha-\mathrm{SrMnO}_{3}, \mathrm{SrM}_{3} \mathrm{O}_{x}$ & $\alpha-\mathrm{SrMnO}_{3}, \mathrm{SrMn}_{3} \mathrm{O}_{x}$ & $\alpha-\mathrm{SrMnO}_{3}, \mathrm{SrMn}_{3} \mathrm{O}_{x}$ \\
\hline $1: 2$ & $\alpha-\mathrm{SrMnO}_{3}, \mathrm{SrMn}_{3} \mathrm{O}_{x}$ & $\alpha-\mathrm{SrMnO}_{3}, \mathrm{SrMn}_{3} \mathrm{O}_{x}$ & $\alpha-\mathrm{SrMnO}_{3}, \mathrm{SrMn}_{3} \mathrm{O}_{x}$ \\
\hline $1: 3$ & $\mathrm{SrMn}_{3} \mathrm{O}_{x}$ & $\mathrm{SrMn}_{3} \mathrm{O}_{x}$ & $\mathrm{SrMn}_{3} \mathrm{O}_{x}$ \\
\hline $1: 4$ & $\mathrm{SrMn}_{3} \mathrm{O}_{x}, \mathrm{Mn}_{3} \mathrm{O}_{3}$ & $\mathrm{SrMn}_{3} \mathrm{O}_{x}, \mathrm{Mn}_{3} \mathrm{O}_{4}$ & $\mathrm{SrMn}_{3} \mathrm{O}_{x}, \mathrm{Mn}_{3} \mathrm{O}_{4}$ \\
\hline $1: 6$ & $\mathrm{Mn}_{2} \mathrm{O}_{3}, *$ & $\mathrm{SrMn}_{3} \mathrm{O}_{x}, \mathrm{Mn}_{3} \mathrm{O}_{4}$ & $\mathrm{SrMn}_{3} \mathrm{O}_{x}, \quad \mathrm{Mn}_{3} \mathrm{O}_{4}$ \\
\hline $1: 12$ & $\mathrm{Mn}_{2} \mathrm{O}_{3}, *$ & $\mathrm{SrMn}_{3} \mathrm{O}_{x}, \mathrm{Mn}_{3} \mathrm{O}_{4}$ & \\
\hline
\end{tabular}

${ }^{\circ} \mathrm{C}$ 以上で融解する。

低温型複酸化物の X線回折図形々回折数值とを図 1 , 表 2 お よ び表 3 に示す。なお，これらの化合物の詳細に関しては別に報告 する。

表 $2 \alpha-\mathrm{SrMnO}_{3}$ のX線回折数值

\begin{tabular}{|c|c|c|c|c|c|c|c|}
\hline \multirow{2}{*}{$h k l$} & \multicolumn{2}{|c|}{ Syono 5 (1969) } & \multicolumn{2}{|r|}{ 本 } & \multirow{2}{*}{$\frac{\text { 奏 }}{1 / d^{2} \text { obs. }}$} & \multicolumn{2}{|l|}{ 験 } \\
\hline & $d_{\text {obs. }}(\AA)$ & $I / I_{1}$ & $2 \theta\left({ }^{\circ}\right)$ & $d_{\text {obs. }}(\AA)$ & & $1 / d^{2}$ calc. & $I / I_{1}$ \\
\hline 100 & ......... & $\cdots \cdots$ & 18.79 & 4.72 & 0.0448 & 0.0449 & 5 \\
\hline 102 & 3.276 & s & 27.23 & 3.28 & 0.0932 & 0.0934 & 48 \\
\hline 110 & 2.726 & $\mathrm{v} \mathrm{s}$ & 37.84 & 2.73 & 0.1347 & 0.1348 & 100 \\
\hline 103 & 2.550 & $\mathrm{~m}$ & 35.20 & 2.55 & 0.1541 & 0.1540 & 45 \\
\hline 201 & 2.282 & $\mathbf{w}$ & 39.44 & 2.283 & 0.1919 & 0.1919 & 6 \\
\hline 004 & 2.271 & $\mathbf{w}$ & 39.68 & 2. 270 & 0.1942 & 0.1938 & 7 \\
\hline 202 & 2.094 & $\mathbf{s}$ & 43.19 & 2.093 & 0.2283 & 0.2283 & 47 \\
\hline 104 & 2.047 & $\mathrm{w}$ & 44.25 & 2.045 & 0.2391 & 0.2388 & 7 \\
\hline 203 & 1.8613 & $\mathrm{~m}$ & 48.91 & 1.861 & 0.2889 & 0.2888 & 29 \\
\hline 114 & .......... & ...... & 52.45 & 1.743 & 0.3291 & 0.3286 & 1 \\
\hline 105 & 1.6955 & $\mathrm{v} \mathbf{w}$ & 54.08 & 1.694 & 0.3483 & 0.3478 & 5 \\
\hline 212 & 1.6601 & $\mathbf{w}$ & 55.31 & 1.660 & 0.3631 & 0.3631 & 8 \\
\hline 204 & 1.6364 & $\mathrm{v} w$ & 56.20 & 1.635 & 0.3739 & 0.3736 & 5 \\
\hline 300 & 1.5732 & $\mathrm{~m}$ & 58.67 & 1.572 & 0.4046 & 0.4046 & 12 \\
\hline 213 & 1.5370 & $\mathrm{w}$ & 60.18 & 1.536 & 0.4237 & 0.4237 & 16 \\
\hline 205 & ............ & $\ldots \ldots$ & 64.77 & 1.438 & 0.4835 & 0.4832 & 8 \\
\hline 214 & 1.4409 & $\mathrm{v} \mathrm{w}$ & 66.66 & 1.402 & 0.5089 & 0.5085 & 4 \\
\hline 220 & 1.3621 & $\mathrm{~m}$ & 68.90 & 1.362 & 0.5394 & 0.5394 & 14 \\
\hline $\left.\begin{array}{l}215 \\
206\end{array}\right\}$ & & & 74.48 & 1.273 & 0.6173 & 0.6175 & 12 \\
\hline 312 & & & 75.56 & 1.257 & 0.6326 & 0.6328 & 4 \\
\hline 313 & & & 79.78 & 1.201 & 0.6932 & 0.6934 & 5 \\
\hline 224 & & & 82.53 & 1.1679 & 0.7331 & 0.7332 & 3 \\
\hline 216 & & & 83.75 & 1.1539 & 0.7510 & 0.7508 & 4 \\
\hline 402 & & & 84.88 & 1.1414 & 0.7676 & 0.7677 & 3 \\
\hline 314 & & & 85.55 & 1.1342 & 0.7774 & 0.7780 & 3 \\
\hline 403 & & & 88.98 & 1.0991 & 0.8278 & 0.8280 & 3 \\
\hline 315 & & & 93.00 & 1.0619 & 0.8868 & 0.8870 & 4 \\
\hline 322 & & & 94.04 & 1.0528 & 0.9022 & 0.9025 & 3 \\
\hline $\left.\begin{array}{l}118 \\
404\end{array}\right\}$ & & & 94.64 & 1.0477 & 0.9110 & 0.9100 & 7 \\
\hline 410 & & & 96.86 & 1.0296 & 0.9433 & 0.9440 & 5 \\
\hline 323 & & & 98.19 & 1.0191 & 0.9629 & 0.9631 & 3 \\
\hline 316 & & & 102.20 & 0.9897 & 1.0208 & 1.0204 & 3 \\
\hline 408 & & & 111.80 & 0.9302 & 1.1557 & 1.1553 & 4 \\
\hline $\left.\begin{array}{l}308 \\
218\end{array}\right\}$ & & & 113.63 & 0.9203 & 1.1805 & 1.1797 & 3 \\
\hline 330 & & & 116.10 & 0.9078 & 1.2135 & 1.2138 & 2 \\
\hline 503 & & & 117.54 & 0.9008 & 1.2324 & 1.2328 & 2 \\
\hline 326 & & & 122.09 & 0.8803 & 1.2904 & 1. 2902 & 3 \\
\hline 422 & & & 123.45 & 0.8746 & 1.3060 & 1.3071 & 3 \\
\hline 504 & & & 124.20 & 0.8716 & 1.3162 & 1.3176 & 5 \\
\hline 423 & & & 128.50 & 0.8552 & 1.3665 & 1. 3677 & 4 \\
\hline 513 & & & 141.50 & 0.8159 & 1.5023 & 1.5026 & 3 \\
\hline 425 & & & 148.50 & 0.8003 & 1.5613 & 1.5615 & 1 \\
\hline
\end{tabular}

$\mathrm{Cu} K_{\alpha}$, 六方唱系, $a_{0}=5.447 \pm 0.001 \AA ， c_{0}=9.081 \pm 0.002 \AA$

*1 含有マンガンがすべて $\mathrm{Mn}^{4+}$ とすれば $\mathrm{SrMn}_{3} \mathrm{O}_{7}, \mathrm{Mn}^{3+}$ と すれば $\mathrm{SrMn}_{3} \mathrm{O}_{5.5},\left[\mathrm{Mn}_{2}{ }^{3+} \mathrm{Mn}^{4+}\right]$ と仮定すれば $\mathrm{SrMn}_{3} \mathrm{O}_{6}$ となる。

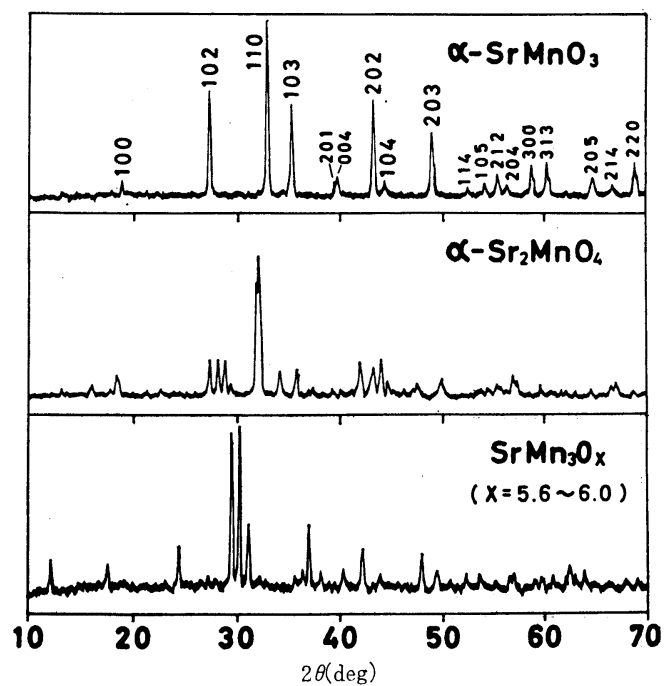

図 1 低温型複酸化物の $\mathrm{X}$ 線回折図形 $\left(\mathrm{Cu} K_{\alpha}\right)$

表 $3 \alpha-\mathrm{Sr}_{2} \mathrm{MnO}_{4}$ と $\mathrm{SrMn}_{3} \mathrm{O}_{x}(x=5.6 \sim 6.0)$ の $\mathrm{X}$ 線回折数值*

$\alpha-\mathrm{Sr}_{2} \mathrm{MnO}_{4} \quad \mathrm{SrMn}_{3} \mathrm{O}_{x}(x=5.6 \sim 6.0)$

\begin{tabular}{|c|c|c|c|c|c|}
\hline \multicolumn{3}{|c|}{$\alpha-\mathrm{Sr}_{2} \mathrm{MnO}_{4}$} & \multicolumn{3}{|c|}{$\mathrm{SrMn}_{3} \mathrm{O}_{x}(x=5.6 \sim 6.0)$} \\
\hline $2 \theta\left({ }^{\circ}\right)$ & $d(\AA)$ & $I / I_{1}$ & $2 \theta\left({ }^{\circ}\right)$ & $d(\AA)$ & $I / I_{1}$ \\
\hline 12.9 & 6.84 & 5 & 12.1 & 7.31 & 20 \\
\hline 15.9 & 5.57 & 7 & 17.5 & 5.07 & 15 \\
\hline 18.2 & 4.88 & 15 & 24.4 & 3.65 & 26 \\
\hline 27.4 & 3.26 & 26 & 29.4 & 3.04 & 96 \\
\hline 28.2 & 3.16 & 27 & 30.2 & 2.96 & 100 \\
\hline 28.85 & 3.09 & 25 & 31.1 & 2.88 & 39 \\
\hline 29.3 & 3.05 & 9 & 35.5 & 2.53 & 9 \\
\hline 31.9 & 2.81 & 86 & 36.4 & 2.47 & 12 \\
\hline 32.1 & 2.79 & 100 & 36.9 & 2.44 & 29 \\
\hline 34.2 & 2.62 & 18 & 38.1 & 2.36 & 11 \\
\hline 35.8 & 2.51 & 19 & 40.3 & 2. 237 & 12 \\
\hline 42.0 & 2. 242 & 24 & 42.2 & 2.144 & 24 \\
\hline 43.3 & 2.090 & 22 & 43.8 & 2.068 & 9 \\
\hline 44.1 & 2.053 & 27 & 47.9 & 1.899 & 23 \\
\hline 44.7 & 2.027 & 11 & 49.4 & 1.848 & 13 \\
\hline 47.6 & 1.910 & 8 & & & \\
\hline 50.0 & 1.824 & 13 & & & \\
\hline $\mathrm{Cu} K_{\alpha}$ & $\theta=50^{\circ}$ & の主要 & sw & & \\
\hline
\end{tabular}

\section{$3 \cdot 2$ 高温型複酸化物}

前節では比較的低温度の熱処理で得られる一連の複酸化物につ いて述べたが，ここでは，それよりも高い温度で生成する数種類 の化合物について説明する。種々の混合比の反応体を，空気中で $1400^{\circ} \mathrm{C}$ 以上に加熱した際の反応生成物を表 4 亿示す。 $\beta-\mathrm{SrMnO}_{3}$ および $\mathrm{Sr}_{3} \mathrm{Mn}_{2} \mathrm{O}_{7}$ は従来報告されていない新化合物である。ま た，表 4 中で, $\mathrm{Sr}_{4} \mathrm{Mn}_{3} \mathrm{O}_{10}$ は $\mathrm{Sr}: \mathrm{Mn}$ モル比がほぼ 4:2.9 
$4: 3.1$, 反応温度が $1400 \sim 1500^{\circ} \mathrm{C}$ のご く限られた領域で生成し，しかも得られ るX線回折図形は反応時間や冷却方法の わずかな違いでも部分的に差が認められ るが, 主要回折線は $d_{1}=2.77 \AA, \quad I_{1}=$ $100, d_{2}=2.07 \AA, \quad I_{2}=88, d_{3}=2.94 \AA$, $I_{3}=80, d_{4}=3.10 \AA, \quad I_{4}=66$ などであ

る。なおこの化合物は回折線の位置から考学て 4 で述べる正方晶 層状構造の $\mathrm{Sr}_{4} \mathrm{Mn}_{3} \mathrm{O}_{10}$ とは異なった構造を持っている。これ以 外の生成物について以下に詳述する。

$3 \cdot 2 \cdot 1 \quad \beta-\mathrm{SrMnO}_{3} \mathrm{Sr}: \mathrm{Mn}($ モル比 $)=1: 1$ の反応体を空気 中で $1200^{\circ} \mathrm{C}$ に加熱したものは高温型 $\mathrm{BaMnO}_{3}$ (六方晶系) と同 形の低温型 $\alpha-\mathrm{SrMnO}_{3}$ であったが，これを $1500^{\circ} \mathrm{C}$ 以上の高温 で加熱して $300^{\circ} \mathrm{C}$ 位まで急冷すると立方晶系ぺロブスカイト構造 の高温型 $\beta-\mathrm{SrMnO}_{3}$ が得られる。この化合物は黒灰色で低温型 の $\alpha-\mathrm{SrMnO}_{3}$ に認められた青味はない。 $1650^{\circ} \mathrm{C}$ に 5 時間加熱後 急冷した試料について測定したX線回折データを図 2 と表 5 に示 す。格子定数は $a_{0}=3.805 \pm 0.002 \AA$ である。ペロブスカイト型 $\beta-\mathrm{SrMnO}_{3}$ の合成には急冷の操作が重要である。たとえば, 1600 ${ }^{\circ} \mathrm{C}$ から $1000^{\circ} \mathrm{C}$ まで 1 時間かけて冷却した試料は低温型であり, またいったん急冷して得られた高温型 $\beta-\mathrm{SrMnO}_{3}$ を $1200^{\circ} \mathrm{C} て ゙$

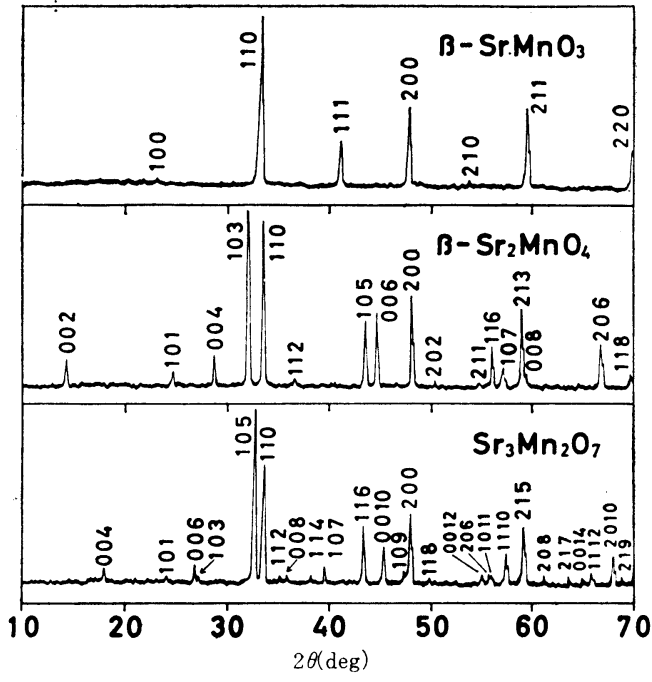

図 2 高温型複酸化物の $\mathrm{X}$ 線回折図形 $\left(\mathrm{Cu} K_{\alpha}\right)$

表 $5 \beta-\mathrm{SrMnO}_{3}$ のX線回折数值

\begin{tabular}{|c|c|c|c|c|}
\hline$h k l$ & $2 \theta\left(^{\circ}\right)$ & $d(\AA)$ & $I / I_{1}$ & $a_{0}(\stackrel{\AA}{\AA})$ \\
\hline 100 & 23.36 & 3.805 & $<1$ & 3.805 \\
\hline 110 & 33.26 & 2.691 & 100 & 3. 8061 \\
\hline 111 & 41.04 & 2.197 & 14 & 3.8061 \\
\hline 200 & 47.75 & 1.903 & 34 & 3.8062 \\
\hline 210 & 53.82 & 1.702 & $<1$ & 3. 8056 \\
\hline 211 & 59.44 & 1.554 & 31 & 3.8058 \\
\hline 220 & 69.84 & 1.346 & 14 & 3. 8059 \\
\hline 310 & 79.59 & 1.2034 & 11 & 3.8055 \\
\hline 311 & 84.33 & 1.1475 & 3 & 3.8058 \\
\hline 222 & 89.03 & 1.0986 & 5 & 3.8057 \\
\hline 321 & 98.46 & 1.0171 & 13 & 3. 8057 \\
\hline 400 & 108.11 & 0.9514 & 2 & 3.8057 \\
\hline $\left.\begin{array}{lll}4 & 1 & 1 \\
3 & 3 & 0\end{array}\right)$ & 118.34 & 0.8970 & 9 & 3. 8057 \\
\hline 331 & 123.81 & 0.8731 & $<1$ & 3. 8059 \\
\hline 420 & 129.67 & 0.8510 & 9 & 3.8058 \\
\hline 332 & 143.35 & 0.8114 & 7 & 3.8058 \\
\hline
\end{tabular}

表 4 高温型複酸化物の生成状況

\begin{tabular}{|c|c|c|c|}
\hline 1500 & 1600 & 1700 & 1800 \\
\hline 5 & 5 & 5 & 2 \\
\hline$-\mathrm{Sr}_{2} \mathrm{MnO}_{4}$ & $\beta-\mathrm{Sr}_{2} \mathrm{MnO}_{4}$ & $\beta-\mathrm{Sr}_{2} \mathrm{MnO}_{4}$ & \\
\hline $\begin{array}{l}-\mathrm{Sr}_{2} \mathrm{MnO}_{4} \\
\mathrm{r}_{4} \mathrm{Mn}_{3} \mathrm{O}_{10}\end{array}$ & $\left\{\begin{array}{l}\beta-\mathrm{Sr}_{2} \mathrm{MnO}_{4} \\
\beta-\mathrm{SrMnO}_{3}\end{array}\right.$ & $\mathrm{Sr}_{3} \mathrm{Mn}_{2} \mathrm{O}_{7}$ & $\mathrm{Sr}_{3} \mathrm{Mn}_{2} \mathrm{O}_{7}$ \\
\hline $\mathrm{rr}_{4} \mathrm{Mn}_{3} \mathrm{O}_{10}$ & $\left\{\begin{array}{l}\beta-\mathrm{Sr}_{2} \mathrm{MnO}_{4} \\
\beta-\mathrm{SrMnO}_{3}\end{array}\right.$ & $\mathrm{Sr}_{3} \mathrm{Mn}_{2} \mathrm{O}_{7}$ & $\mathrm{Sr}_{3} \mathrm{Mn}_{2} \mathrm{O}_{7}$ \\
\hline$-\mathrm{SrMnO}_{3}$ & $\beta-\mathrm{SrMnO}_{3}$ & $\beta-\mathrm{SrMnO}_{3}$ & \\
\hline
\end{tabular}

\section{** 焼成時間 $(\mathrm{hr})$}

8 時間再加熱後急冷した試料も $\alpha-\mathrm{SrMnO}_{3}$ である。

化学分析によれば，本実験で得られた $\beta \cdots \mathrm{SrMnO}_{3}$ 中の全マン ガン量に対する $\mathrm{Mn}^{4+}$ イオンの含有率は表 8 に示すように平均 $96 \%$ で，これを示性式になおすと $\beta-\mathrm{SrMnO}_{2.98}$ に相当する。ま た， $3 \cdot 1$ で述べた $\alpha-\mathrm{SrMnO}_{3}$ のそれは平均 $98 \%, \alpha-\mathrm{SrMnO}_{2.99}$

表 $6 \quad \beta-\mathrm{Sr}_{2} \mathrm{MnO}_{4}$ の X 線回折数値

\begin{tabular}{|c|c|c|c|c|c|}
\hline$h k l$ & $2 \theta\left({ }^{\circ}\right)$ & $d_{\text {obs. }}$ (A) & $1 / d^{2}$ obs. & $1 / d^{2}$ calc. & $I / I_{1}$ \\
\hline 002 & 14.2 & 6.24 & 0.0257 & 0.0256 & 8 \\
\hline 101 & 24.6 & 3.62 & 0.0772 & 0.0761 & 7 \\
\hline 004 & 28.6 & 3.12 & 0.1028 & 0.1025 & 9 \\
\hline 103 & 31.9 & 2.80 & 0.1276 & 0.1274 & 100 \\
\hline 110 & 33.45 & 2.676 & 0.1396 & 0.1395 & 57 \\
\hline 112 & 36.49 & 2.460 & 0.1652 & 0.1651 & 3 \\
\hline 105 & 43.40 & 2.083 & 0.2304 & 0.2299 & 28 \\
\hline 006 & 43.46 & 2.081 & 0.2310 & 0.2306 & \\
\hline 114 & 44.54 & 2.033 & 0.2421 & 0.2419 & 25 \\
\hline 200 & 48.01 & 1.893 & 0.2788 & 0.2789 & 27 \\
\hline 202 & 50.38 & 1.810 & 0.3053 & 0.3045 & 1 \\
\hline 211 & 54.65 & 1.678 & 0.3551 & 0.3551 & 2 \\
\hline 116 & 55.82 & 1.643 & 0.3705 & 0.3700 & 15 \\
\hline 204 & 56.83 & 1.619 & 0.3817 & 0.3814 & 4 \\
\hline 107 & 57.02 & 1.614 & 0.3840 & 0.3836 & 5 \\
\hline 213 & 58.83 & 1.568 & 0.4065 & 0.4063 & 28 \\
\hline 008 & 59.16 & 1.560 & 0.4108 & 0.4099 & 3 \\
\hline 206 & 66.71 & 1.401 & 0.5095 & 0.5095 & 15 \\
\hline 118 & 69.65 & 1.349 & 0.5497 & 0.5494 & 4 \\
\hline 220 & 70.23 & 1.339 & 0.5577 & 0.5578 & 8 \\
\hline 109 & 72.48 & 1.303 & 0.5891 & 0.5885 & 2 \\
\hline 224 & 77.50 & 1.231 & 0.6603 & $0 . \$ 603$ & 2 \\
\hline 217 & 77.60 & 1.229 & 0.6626 & 0.6625 & 3 \\
\hline 303 & 79.21 & 1.208 & 0.6849 & 0.6852 & 5 \\
\hline 208 & 79.48 & 1.205 & 0.6887 & 0.6888 & 6 \\
\hline 310 & 80.03 & 1.1979 & 0.6969 & 0.6973 & 6 \\
\hline $1 \cdot 1 \cdot 10$ & 85.75 & 1.1321 & 0.7802 & 0.7800 & 4 \\
\hline $\left.\begin{array}{lll}3 & 0 & 5 \\
2 & 2 & 6\end{array}\right\}$ & 86.28 & 1.1265 & 0.7880 & 0.7884 & 6 \\
\hline 314 & 87.05 & 1.1185 & 0.7994 & 0.7998 & 5 \\
\hline $1 \cdot 0 \cdot 11$ & 90.16 & 1.0878 & 0.8451 & 0.8447 & 5 \\
\hline 219 & 91.68 & 1.0737 & 0.8675 & 0.8675 & 2 \\
\hline $2 \cdot 0 \cdot 10$ & 95.23 & 1.0428 & 0.9197 & 0.9194 & 2 \\
\hline 316 & 95.76 & 1.0838 & 0.9276 & 0.9279 & 6 \\
\hline 307 & 96.66 & 1.0311 & 0.9405 & 0.9414 & 1 \\
\hline 323 & 98.25 & 1.0187 & 0.9635 & 0.9641 & 8 \\
\hline 228 & 98.55 & 1.0164 & 0.9681 & 0.9678 & 7 \\
\hline 325 & 105.38 & 0.9684 & 1.0654 & 1.0666 & 2 \\
\hline 318 & 108.26 & 0.9504 & 1.1069 & 1.1072 & 4 \\
\hline 400 & 108.84 & 0.9470 & 1.1147 & 1.1157 & 2 \\
\hline $2 \cdot 1 \cdot 11$ & 109.47 & 0.9434 & 1.1236 & 1.1237 & 10 \\
\hline $2 \cdot 2 \cdot 10$ & 114.95 & 0.9135 & 1.1984 & 1.1983 & $<1$ \\
\hline 404 & 116.43 & 0.9062 & 1. 2177 & 1.2182 & 1 \\
\hline 327 & 116.59 & 0.9038 & 1. 2199 & 1.2203 & 2 \\
\hline 413 & 118.29 & 0.8971 & 1. 2426 & 1.2431 & 7 \\
\hline 330 & 119.25 & 0.8926 & 1.2544 & 1.2551 & 4 \\
\hline $3 \cdot 1 \cdot 10$ & 125.96 & 0.8646 & 1.3377 & 1.3378 & 6 \\
\hline 415 & 126.58 & 0.8623 & 1.3449 & 1. 3455 & 9 \\
\hline 334 & 127.58 & 0.8585 & 1.3565 & 1.3576 & 2 \\
\hline 420 & 130.88 & 0.8469 & 1.3943 & 1.3946 & 16 \\
\hline 329 & 133.69 & 0.8377 & 1.4247 & 1.4253 & 2 \\
\hline $2 \cdot 1 \cdot 13$ & 134.33 & 0.8353 & 1.4316 & 1.4311 & 2 \\
\hline 336 & 139.65 & 0.8205 & 1. 4852 & 1. 4857 & 1 \\
\hline 424 & 141.00 & 0.8171 & 1.4977 & 1.4971 & 4 \\
\hline 408 & 144.06 & 0.8098 & 1.5249 & 1.5256 & 3 \\
\hline $3 \cdot 2 \cdot 10$ & 145.17 & 0.8073 & 1.5341 & 1.5343 & 17 \\
\hline
\end{tabular}


表 $7 \mathrm{Sr}_{3} \mathrm{Mn}_{2} \mathrm{O}_{7}$ の $\mathrm{X}$ 線回折数值

\begin{tabular}{|c|c|c|c|c|c|}
\hline$h l k$ & $2 \theta\left({ }^{\circ}\right)$ & $1 / d_{\text {obs. }}(\AA)$ & $1 / a^{2}$ obs. & $1 / d^{2}$ calc. & $I / I_{1}$ \\
\hline 002 & 8.83 & 10.0 & 0.0099 & 0.0099 & 7 \\
\hline 004 & 17.65 & 5.02 & 0.0396 & 0.0399 & 7 \\
\hline 101 & 23.80 & 3.74 & 0.0715 & 0.0716 & 3 \\
\hline 006 & 26.65 & 3.35 & 0.0894 & 0.0894 & 11 \\
\hline 103 & 26.97 & 3.31 & 0.0915 & 0.0916 & 2 \\
\hline 105 & 32.42 & 2.76 & 0.1312 & 0.1313 & 100 \\
\hline 110 & 33.34 & 2.69 & 0.1385 & 0.1386 & 53 \\
\hline 112 & 34.48 & 2.60 & 0.1481 & 0.1484 & 1 \\
\hline 008 & 35.74 & 2.511 & 0.1587 & 0.1585 & 1 \\
\hline 114 & 37.95 & 2.369 & 0.1782 & 0.1782 & 2 \\
\hline 107 & 39. 32 & 2. 289 & 0.1909 & 0.1909 & 8 \\
\hline 116 & 43.11 & 2.097 & 0.2276 & 0.2279 & 24 \\
\hline $0 \cdot 0 \cdot 10$ & 45.14 & 2.007 & 0.2483 & 0.2485 & 23 \\
\hline 109 & 47.21 & 1.923 & 0.2705 & 0.2706 & 4 \\
\hline 200 & 47.82 & 1.901 & 0.2769 & 0.2769 & 24 \\
\hline 118 & 49.68 & 1.834 & 0.2975 & 0.2975 & 3 \\
\hline $0 \cdot 0 \cdot 12$ & 54.84 & 1.673 & 0.3574 & 0.3576 & 4 \\
\hline 206 & 55.58 & 1.652 & 0.3664 & 0.3664 & 3 \\
\hline $1.0 \cdot 11$ & 55.83 & 1.645 & 0.3694 & 0.3697 & 4 \\
\hline $1 \cdot 1 \cdot 10$ & 57.25 & 1.608 & 0.3869 & 0.3869 & 18 \\
\hline 215 & 58.97 & 1.565 & 0.4083 & 0.4083 & 40 \\
\hline 208 & 61.16 & 1.514 & 0.4363 & 0.4366 & 1 \\
\hline 217 & 63.60 & 1.462 & 0.4680 & 0.4681 & 4 \\
\hline $0.0 \cdot 14$ & 65.04 & 1.433 & 0.4871 & 0.4874 & 1 \\
\hline $1 \cdot 1 \cdot 12$ & 65.70 & 1.420 & 0.4959 & 0.4960 & 4 \\
\hline $2 \cdot 0 \cdot 10$ & 67.86 & 1.380 & 0.5252 & 0.5253 & 14 \\
\hline 219 & 69.47 & 1. 352 & 0.5473 & 0.5474 & 2 \\
\hline 220 & 69.97 & 1.343 & 0.5541 & 0.5543 & 10 \\
\hline $1 \cdot 1 \cdot 14$ & 75.00 & 1.265 & 0.6246 & 0.6250 & 1 \\
\hline $1 \cdot 0 \cdot 15$ & 75.22 & 1. 262 & 0.6277 & 0.6279 & 2 \\
\hline $2 \cdot 0 \cdot 12$ & 75.67 & 1.256 & 0.6343 & 0.6345 & 5 \\
\hline 226 & 76.35 & 1.246 & 0.6439 & 0.6440 & \\
\hline $2 \cdot 1 \cdot 11$ & 76.54 & 1.244 & 0.6467 & 0.6468 & 4 \\
\hline 3.05 & 79.20 & 1.208 & 0.6848 & 0.6852 & 8 \\
\hline 310 & 79.73 & 1.202 & 0.6926 & 0.6927 & 10 \\
\hline $1 \cdot 1 \cdot 16$ & 85.29 & 1.137 & 0.7735 & 0.7740 & 4 \\
\hline 316 & 85.84 & 1.1377 & 0.7816 & 0.7818 & 4 \\
\hline $1 \cdot 0 \cdot 17$ & 86.15 & 1.1278 & 0.7862 & 0.7868 & 5 \\
\hline $2 \cdot 2 \cdot 10$ & 87.23 & 1.1166 & 0.8021 & 0.8028 & 7 \\
\hline $2 \cdot 1 \cdot 15$ & 94.21 & 1.0514 & 0.9046 & 0.9043 & 3 \\
\hline $2 \cdot 2 \cdot 10$ & 94.68 & 1.0474 & 0.9115 & 0.9115 & 3 \\
\hline $3 \cdot 1 \cdot 10$ & 96.65 & 1.0312 & 0.9403 & 0.9407 & 5 \\
\hline 325 & 98.11 & 1.0197 & 0.9678 & 0.9681 & 6 \\
\hline $3 \cdot 1 \cdot 12$ & 104.21 & 0.9761 & 1.0496 & 1.0499 & 2 \\
\hline $\left.\begin{array}{l}2 \cdot 1 \cdot 17 \\
1 \cdot 0 \cdot 20\end{array}\right\}$ & 105.16 & 0.9699 & 1.0630 & 1.0625 & 6 \\
\hline 400 & 108.28 & 0.9504 & 1.1069 & 1.1078 & 3 \\
\hline $3 \cdot 2 \cdot 11$ & 115.10 & 0.9128 & 1. 2001 & 1.2005 & 2 \\
\hline 415 & 118.10 & 0.8981 & 1.2397 & 1.2402 & 7 \\
\hline $2 \cdot 1 \cdot 19$ & 118.27 & 0.8973 & 1. 2417 & 1.2426 & 3 \\
\hline $3 \cdot 1 \cdot 16$ & 125.14 & 0.8678 & 1.3278 & 1.3280 & 4 \\
\hline $\left.\begin{array}{l}2 \cdot 1 \cdot 20 \\
1 \cdot 1 \cdot 22\end{array}\right\}$ & 126.11 & 0.8641 & 1.3393 & 1.3395 & 8 \\
\hline $4 \cdot 0 \cdot 10$ & 127.47 & 0.8589 & 1.3554 & 1.3560 & 3 \\
\hline 420 & 129.97 & 0.8500 & 1.3839 & 1. 3847 & 6 \\
\hline $4 \cdot 1 \cdot 11$ & 138.90 & 0.8226 & 1.4777 & 1.4778 & 8 \\
\hline
\end{tabular}

で，本実験に打ける化学分析の精度（ $\pm 5 \%$ 以内）から考兄て $\alpha$ 型と $\beta$ 型とは， ほとんど同一の化学組成を持っていると考兄られ る。

なお，著者らはやや酸素欠陥の多い $\beta-\mathrm{SrMnO}_{3-\delta}$ の合成とそ の酸化反応についても研究を行なっているが，これについては次 報で述べる。

$3 \cdot 2 \cdot 2 \beta-\mathrm{Sr}_{2} \mathrm{MnO}_{4} \mathrm{Sr}: \mathrm{Mn}=2: 1$ の試料を空気中で $1600^{\circ} \mathrm{C}$ 以上に加熱すると低温型 $\alpha-\mathrm{Sr}_{2} \mathrm{MnO}_{4}$ とは異なるX線回折図形を 与える。 $1700^{\circ} \mathrm{C} て ゙ 5$ 時間加熱処理した試料について測定したX 線回折データを図 2 と表 6 に示す。X線回折数值は Baltz ら ${ }^{4)}$ に よって指摘されている正方晶系の $\mathrm{K}_{2} \mathrm{NiF}_{4}$ 型構造と一致し, 格子 定数は $a_{0}=3.787 \pm 0.002 \AA, c_{0}=12.495 \pm 0.005 \AA, c_{0} / a_{0}=3.301$ \pm 0.002 である。この高温型 $\beta-\mathrm{Sr}_{2} \mathrm{MnO}_{4}$ は低温型と違って黒灰 色である。この化合物は $\beta-\mathrm{SrMnO}_{3}$ と異なり急冷する必要はな い。すなわち, 毎分 $10^{\circ} \mathrm{C}$ 程度の冷却では変化がなく, $1200^{\circ} \mathrm{C}$ に 8 時間保持すると低温型が混入し， $1350^{\circ} \mathrm{C} に 8$ 時間保持する と完全に $\alpha-\mathrm{Sr}_{2} \mathrm{MnO}_{4}$ に転移する。

3.2.3 $\quad \mathrm{Sr}_{3} \mathbf{M n}_{2} \mathbf{O}_{7} \mathrm{Sr}: \mathrm{Mn}$ モル比が $3: 2$ の試料を空気中で $1700^{\circ} \mathrm{C}$ に加熱すると新しい化合物が得られる。 $1700^{\circ} \mathrm{C}$ に時間加 熱した試料についてのX線回折データを, 図 2 と表 7 とに示す。 $\mathrm{Sr}_{3} \mathrm{Mn}_{2} \mathrm{O}_{7}$ のX線回折数値は正方晶系の $\mathrm{Sr}_{3} \mathrm{Ti}_{2} \mathrm{O}_{7}$ のそれ ${ }^{18)}$ 々酷 似し, 格子定数は $a_{0}=3.801 \pm 0.001 \AA, \quad c_{0}=20.06 \pm 0.01 \AA$, $c_{0} / a_{0}=5.278 \pm 0.005$ である。

この化合物は黒色で, 空気中で $1000^{\circ} \mathrm{C}$ に 10 時間再加熱して も変化は認められないが, $1350^{\circ} \mathrm{C} に 14$ 時間加熱すると分解し, そのX線回折図形は表 4 の $\mathrm{Sr}: \mathrm{Mn}=3.2$ の $1300^{\circ} \mathrm{C}, 1400^{\circ} \mathrm{C}$ の 場合の生成物についてのそれと同様で, $\alpha-\mathrm{Sr}_{2} \mathrm{MnO}_{4}$ と $\mathrm{Sr}_{4} \mathrm{Mn}_{3} \mathrm{O}_{10}$ とからなる。

この反応系で生成する各化合物の代表的な合成条件, 性状, 構 造などを表 8 ，図 3 および図 4 にまとめる。

\section{$3 \cdot 3$ 反応におよぼす舜囲気の影響}

一般に固相反応は反応時の雾囲気によって著しい影響を受ける 場合のあることが知られている。この反応系についての雾囲気の 影響についての詳細は別に報告する予定であるが，ここでは $\mathrm{Sr}$ $: \mathrm{Mn}$ モル比が $2: 1$ と $1: 1$ の出発試料について空気, 酸素, 窒素および炭酸ガスのそれぞれの雾囲気中で室温から $1100^{\circ} \mathrm{C}$ で $15 \sim 20^{\circ} \mathrm{C} / \mathrm{min}$ の速度で昇温し $1100^{\circ} \mathrm{C}$ に 8 時間保持した後, その雾囲気中で急冷したものについての分析結果について簡単に 述べる。

空気中での結果についてはすでに $3 \cdot 1$ で述べたが，酸素中で

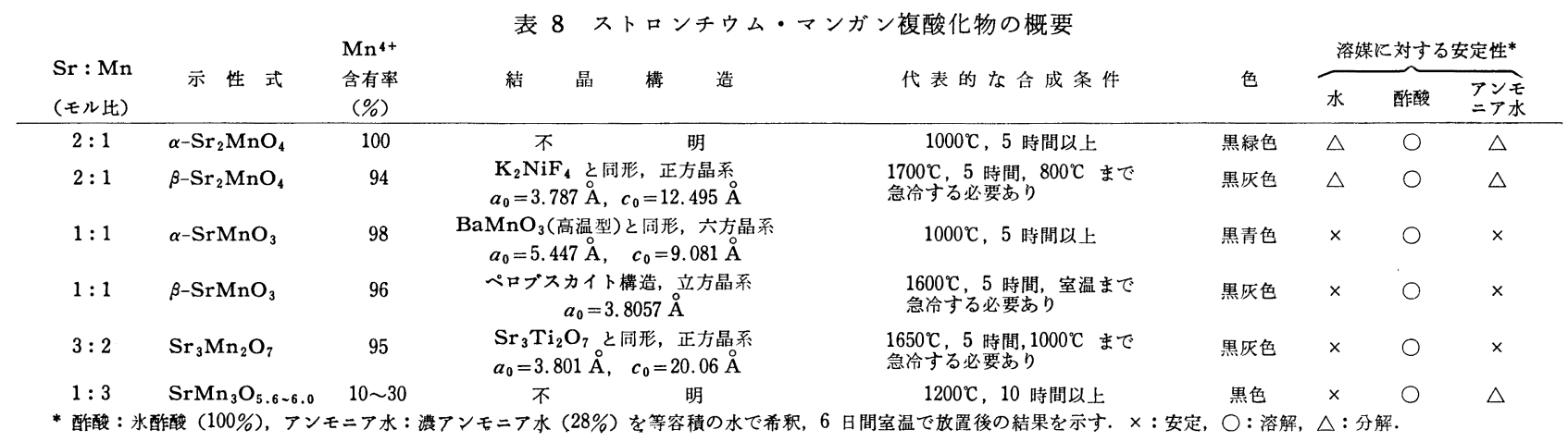

18) ASTM カード, 11-663.

19) H.D. Megaw, Trans. Faraday Soc., A, 42, 124(1946). 


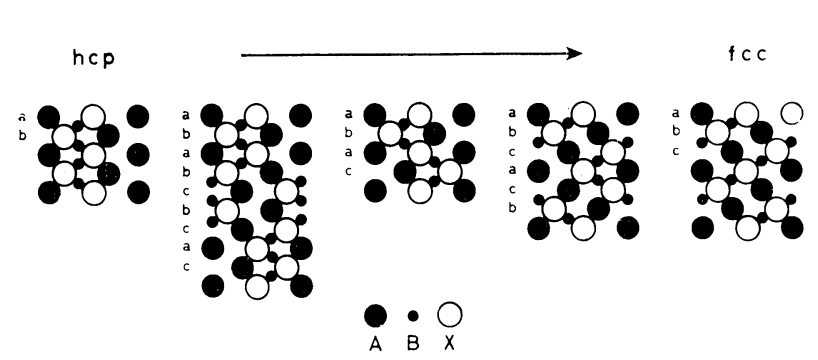

図 3 ペロブスカイト類似化合物の（110）断面図 ${ }^{20)}$

左端は六方最密充填 ( 2 杴周期) の $\mathrm{BaNiO}_{3}$ 構造, ついで 6 枚周期の $\mathrm{BaRuO}_{3}$ 構造, 4 枚周期の高温型 $\mathrm{BaMnO}_{3}$ 構造, 6 杴周期の高温型 $\mathrm{BaTiO}_{3}$ 構造, 右端は立方晶ペロブスカイト構造であり，压力の增加と とも比印の順序儿多形檕移する。

も同様にそれぞれのモル比に対応する低温型化合物が生成する。

窒素雲囲気ではモル比に関係なく $\beta-\mathrm{Sr}_{2} \mathrm{MnO}_{4}$ が生成し, しか もその生成温度は空気悟でのこの化合物の生成温度 $\left(1600^{\circ} \mathrm{C}\right)$ よ りも相当低温である。1:1の昜合には余分のマンガンは $\mathrm{MnO}$ または $\mathrm{Mn}_{3} \mathrm{O}_{4}$ の形で残留する。

炭酸ガス雾囲気では，モル比に関係なくペロブスカイト構造の $\beta-\mathrm{SrMnO}_{3}$ (立方晶系) が優先的に生成する。空気中で加熱する 場合にはこの化合物の生成には $1500^{\circ} \mathrm{C}$ 以上の高温が必要である。 出発試料が $2: 1$ の昜合には余分なストロンチウムは $\mathrm{SrCO}_{3}$ の 形で残留する。これらの結果を表 9 にまとめる。

表 9 各種雱囲気中での反応生成物*

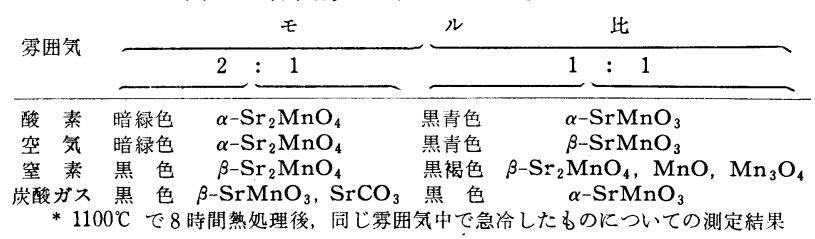

\section{4 考察}

$\mathrm{ABO}_{3}$ 型の立方晶ペロブスカイト構造では図 $4\left(\beta-\mathrm{SrMnO}_{3}\right)$ に 示すようにA (図では $\mathrm{Sr}$ ) は 12 個の0に, B (図では $\mathrm{Mn}$ ) は 6 個の○に囲まれて抢り理想的なパッキングではそれぞれのイオ ン半径 $r_{\mathrm{A}}, r_{\mathrm{B}}$ および $r_{0}$ の間に $r_{\mathrm{A}}+r_{\mathrm{B}}=t \sqrt{2}\left(r_{\mathrm{B}}+r_{0}\right), t=1$ なる関倸が成立する。 Megaw ${ }^{19)}$ によれば，トレランス因子 $t$ の 值が $0.8<t<0.9$ で斜方晶系, $0.9<t<0.97$ では立方晶系, そ して $0.97<t<1.02$ では正方晶系のやや歪んだぺロブスカイト 構造をとるといわれている。 $\beta-\mathrm{SrMnO}_{3}$ の場合. 各イオンの半径 を $\mathrm{Sr}^{2+}: 1.22 \AA, \mathrm{Mn}^{4+}: 0.52 \AA, \mathrm{O}^{2-}: 1.40 \AA$ とすれば $t=$ 0.97 になる。

最近, 六方晶系に属する数種類のペロブスカイト類似構造につ

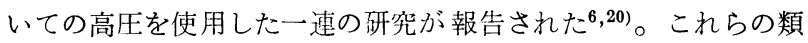
似構造は基本的には立方晶ペロブスカイト構造と密接な関係があ り, $\mathrm{ABX}_{3}$ の $C$ 軸方向への $\mathrm{AX}_{3}$ 原子層の積又重ねのモードが異 なっている（図 3 )。すなわち，六方最密充壃の 2 枚周期の繰り 返しによる $(\mathrm{ab})$ 型, 9 枚周期の (ababcbcac) 型, 4 枚周期の (abac) 型. 6 枚周期の (abcacb) 型および立方最密充填 (3 枚周 期）の (abc) 型とに分類され，そして $\mathrm{BaMnO}_{3}, \mathrm{SrMnO}_{3}, \mathrm{Sr}$. $\mathrm{IrO}_{3}, \mathrm{BaRuO}_{3}, \mathrm{BaTiO}_{3}$ など多数の $\mathrm{ABO}_{3}$ 型化合物について研 究した結果, 圧力の増加とともに上記の順序で相転移が起こるこ と, すなわち六方最密充填の 2 校周期構造から次第に高密度相と

20）庄野，秋本，物性，10，366（1969）。
なり，立方晶ぺロブスカイトが，最高压相であることを述べてい る。 $\mathrm{SrMnO}_{3}$ の場合, 4 枚構造の $\mathrm{SrMnO}_{3}$ ( I ) (高温型 $\mathrm{BaMnO}_{3}$ と同形，本実験では $\alpha$ 型と呼称）を $50 \mathrm{~kb}, 850 \sim 1300^{\circ} \mathrm{C}$ に処理 することによって 6 枚構造の $\mathrm{SrMnO}_{3}$ (II) (高温型 $\mathrm{BaTiO}_{3}$ と同 形）が得られ，立方晶ペロブスカイト構造の $\mathrm{SrMnO}_{3}$ はこれよ りもさらに高い圧力下でなければ生成しないであろらと予想して いる。
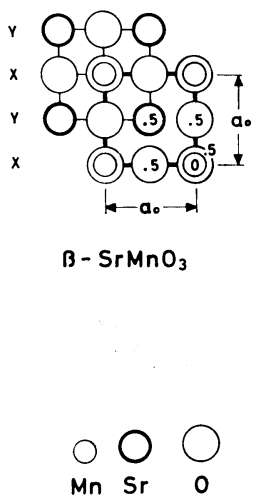

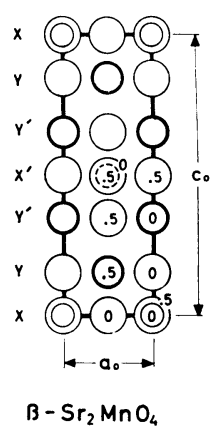

$\mathrm{B}-\mathrm{Sr}_{2} \mathrm{MnO}_{4}$
図 4 高温型複酸化物の結晶構造

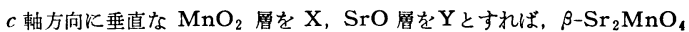
は1 单位の $\beta-\mathrm{SrMnO}_{3}$ 每炕 1 屏の $\mathrm{SrO}$ が, $\mathrm{Sr}_{3} \mathrm{Mn}_{2} \mathrm{O}_{7}$ では 2 単位の $\beta-\mathrm{SrMnO}_{3}$ 每に 1 屏の $\mathrm{SrO}$ 層が拆入された構造である。

しかしながら本実験によって，原料粉末混合物を常圧下空気中 で $1500^{\circ} \mathrm{C}$ 以上に加熱後急冷して, 立方晶へロブスカイト構造の $\beta-\mathrm{SrMnO}_{3}$ を合成し得ることが明らかにされた。市たこの化合物 は炭酸ガス雾囲気では一層低温度の加熱によっても合成できる。

さらに, 著者らは, 雾囲気と熱処理温度との条件を選択して, 同じく常圧下で, 高温型 $\mathrm{BaTiO}_{3}$ 六方晶系と同形の $\gamma-\mathrm{SrMnO}_{3}$ (Syono らはII型と呼称) および Brownmillerite $\left(4 \mathrm{CaO} \cdot \mathrm{Al}_{2} \mathrm{O}_{3}\right.$. $\mathrm{Fe}_{2} \mathrm{O}_{3}$ ) と同形の $\mathrm{SrMnO}_{2.5}$ (斜方晶系) を合成することに成功し て抢り, これらについての詳細は次報で報告する。

次に $\beta-\mathrm{SrMnO}_{3}, \quad \beta-\mathrm{Sr}_{2} \mathrm{MnO}_{4}$ および $\mathrm{Sr}_{3} \mathrm{Mn}_{2} \mathrm{O}_{7}$ 各化合物の結 晶構造の相関関係について考えてみよう。これら化合物の結晶構 造を図 4 亿示す。図で, $c$ 軸方向に垂直な $\mathrm{MnO}_{2}$ 層を $\mathrm{X}, \mathrm{SrO}$ 層を $\mathrm{Y}$ とれば，それぞれの化合物を以下のように表示すること ができる。

$$
\begin{aligned}
& \beta-\mathrm{SrMnO}_{3} \cdots \cdots \cdots \cdots|\mathrm{XY}| \mathrm{XY} \mid \cdots \cdots \cdots \\
& \beta-\mathrm{Sr}_{2} \mathrm{MnO}_{4} \cdots \cdots \cdots \cdots\left|\mathrm{XY} \mathrm{Y}^{\prime} \mathrm{X}^{\prime} \mathrm{Y}^{\prime} \mathrm{Y}\right| \cdots \cdots \cdots \\
& \mathrm{Sr}_{3} \mathrm{Mn}_{2} \mathrm{O}_{7} \cdots \cdots \cdots \cdots \cdot \mathrm{YXY} \mathrm{XY}^{\prime} \mathrm{X}^{\prime} \mathrm{Y}^{\prime} \mathrm{X}^{\prime} \mathrm{Y}^{\prime} \mathrm{Y} \mathrm{X} \mid \cdots \cdots \cdots
\end{aligned}
$$

すなわち, $\beta-\mathrm{SrMnO}_{3}$ を一単位と考兵ると， $\beta-\mathrm{Sr}_{2} \mathrm{MnO}_{4}$ では 一単位ごとに一層の $\mathrm{SrO}$ 層が, $\mathrm{Sr}_{3} \mathrm{Mn}_{2} \mathrm{O}_{7}$ では二単位ごとに一 層の $\mathrm{SrO}$ 層の入った構造, $\mathrm{Sr}_{4} \mathrm{Mn}_{3} \mathrm{O}_{10}\left(a_{0}=3.8 \AA ⿻ c_{0}=28.2 \AA\right.$ と 予想される)*3が考えられるが本実験の範囲では生成しなかった。

一般に，立方晶ペロブスカイト構造を基本とする一連の化合物 $\mathrm{A}_{n} \mathrm{~B}_{n-1} \mathrm{O}_{3 n-2}(n=2,3,4$, ，ずれも正方晶系）の存在が知られ ている系としては $\mathrm{Ca}-\mathrm{Mn}-\mathrm{O}$ 系 ${ }^{16)}, \mathrm{Sr}-\mathrm{Ti}-\mathrm{O}$ 系 ${ }^{21)}$ 抢よび $\mathrm{Sr}-\mathrm{Zr}-\mathrm{O}$ 系22)がある。これらの系でも $n=4$ の化合物の生成域がせまく,

*3 $3 \cdot 2$ 参照.

21) S. N. Ruddlesden, P. Popper, Acta Cryst., 11, 54(1958).

22) T. Noguchi et al., J. Am. Ceram. Soc., 52, 178(1969). 
準安定相と考えられるものが多い。すなわち平衡状態図に示され ていないもの (Ca-Mn-O 系, $\mathrm{Sr}-\mathrm{Hi}-\mathrm{O}$ 系), $n=3$ が混入してく るもの ( $\mathrm{Sr}-\mathrm{Ti}-\mathrm{O}$ 系) や非常に高い温度で処理する必要のあるも の (Ca-Mn-O 系, $\mathrm{Sr}-\mathrm{Zr}-\mathrm{O}$ 系) などでである。

\section{5 ま と め}

(i ) $1200^{\circ} \mathrm{C}$ までの温度で 3 種類の化合物 $\alpha-\mathrm{Sr}_{2} \mathrm{MnO}_{4}, \alpha-$ $\mathrm{SrMnO}_{3}$ および $\mathrm{SrMn}_{3} \mathrm{O}_{x}(x=5.6 \sim 6.0)$ が生成する。このうち $\alpha-\mathrm{SrMnO}_{3}$ は六方晶系の高温型 $\mathrm{BaMnO}_{3}$ と同形である。

(ii) さらに高温では $\mathrm{K}_{2} \mathrm{NiF}_{4}$ 型構造の $\beta-\mathrm{Sr}_{2} \mathrm{MnO}_{4}$, 立方晶
ペロブスカイト型の $\beta-\mathrm{SrMnO}_{3}$, そして $\mathrm{Sr}_{3} \mathrm{Ti}_{2} \mathrm{O}_{7}$ と同形の $\mathrm{Sr}_{3}$ ・ $\mathrm{Mn}_{2} \mathrm{O}_{7}$ が生成する。特に $\beta-\mathrm{SrMnO}_{3}$ は急冷が完全でないと $\alpha$ $\mathrm{SrMn}_{2} \mathrm{O}_{3}$ に転移する。

（iii）雾囲気の影響が著しく，窒素中では $\beta-\mathrm{Sr}_{2} \mathrm{MnO}_{4}$ （高温 型), 炭酸 ガス中では $\beta-\mathrm{SrMnO}_{3}$ (高温型) が優先的にしかも空 気中での場合よりも著しく低温で生成する。

（iv）各複合酸化物の結晶溝造の相関関係について考察した。 本研究を打こなうにあたって，ZAT 炉を使用させて頂いた本 学の谷口雅男助教授に感謝いたします。

\section{ストロンチウム・マンガン複酸化物, $\mathrm{SrMnO}_{3-\delta}(\delta=0 \sim 0.5)$ の酸素欠損と結晶変化 ${ }^{* 1,2}$}

（昭 和 45 年 2 月 7 日 受 理）

水谷惟恭・大隈信行・北沢章生・加藤誠 軌*3

$\mathrm{SrMnO}_{3-\boldsymbol{\delta}}(\delta=0 \sim 0.5)$ なる組成を有する 4 種類の複酸化物について，生成時の雲团気を精細に制御してそれぞれの化合物の生 成条件を調べ，そのさいに生成する酸素久損型化合物の構造，性状ならびに欠損の消減現象について研究を行ない，各化合物相互 の間の結晶転移の状況を明らかにした。

酸素欠損を有する立方晶系ペロブスカイト構造の $\beta-\mathrm{SrMnO}_{3-\delta}(\delta \leq 0.3)$ は原料反応体を空気中で $1500^{\circ} \mathrm{C}$ 以上に加熱し室温ま で急冷するか，高純度炭酸ガス中で $1000 \sim 1100^{\circ} \mathrm{C}$ に加熱し室温まで急冷するさいに得られる。 $\beta-\mathrm{SrMnO}_{3-\delta}$ を空気中で加熱する と $300^{\circ} \mathrm{C}$ 付近で酸素を吸収して欠損が消隇し， $900^{\circ} \mathrm{C}$ 付近で $\alpha$-相に転移し，さらに年温すると $1400^{\circ} \mathrm{C}$ 以上で再び酸素を放出 して $\beta-\mathrm{SrMnO}_{3-\delta}$ となる。これを徐冷すると可逆的に酸素を吸収して $\alpha-\mathrm{SrMnO}_{3}$ になる。

$\gamma-\mathrm{SrMnO}_{3}$ (六方晶系, 高温型 $\mathrm{BaTiO}_{3}$ 構造, $a_{0}=5.460 \AA, c_{0}=13.45 \AA$ ) は炭酸ストロンチウムと炭酸マンガンの等モル混合 物をわずかに酸素を含有する炭酸ガス雾囲気で 1000 ～ $1100^{\circ} \mathrm{C}$ に加熱して得られる。その格子定数は高圧下で合成されたものに比 べてやや大きく，空気中で加熱すると $500^{\circ} \mathrm{C}$ 付近から徐々に $\alpha-\mathrm{SrMnO}_{3}$ に転移する。

ブラウンミラライト構造の $\mathrm{SrMnO}_{2.5}$ (斜方晶系, $a_{0}=5.513 \AA, b_{0}=15.21 \AA, c_{0}=5.369 \AA$ ) は $\alpha-\mathrm{SrMnO}_{3}$ を窒素ガス中で, $1500^{\circ} \mathrm{C}$ に加熱して得られる。これは空気中で加熱すると $300^{\circ} \mathrm{C}$ 付近で酸素を吸収して $\beta-\mathrm{SrMnO}_{3}$ になる。

\section{1 緒言}

複数の原子価をとり得る元素からなる複酸化物にはフェライト など電磁気材料や触媒などとして重要なものが多い。マンガンは $+2,+3,+4$ 等の原子価を有し, その複酸化物の生成反応には 雾囲気中の酸素分圧が，大きな影響を与えることが知られている が，現象は極めて複雑であるためにこれに関する系統的な研究は 非常に少ない。

前報 ${ }^{1)}$ では，ストロンチウム・マンガン複酸化物の生成反応に ついて, 反応体の組成と熱処理の条件をひろく変えて研究した結 果, この反応系で少なくとも 9 種類の複酸化物が生成することを 明らかにした。これらのらち 5 種類は従来知られていない新しい 化合物である。すなわち $1200^{\circ} \mathrm{C}$ までの低温域では $\alpha-\mathrm{SrMnO}_{4}$ (構造未詳), $\alpha-\mathrm{SrMnO}_{3}$ (六方晶系, 高温型 $\mathrm{BaMnO}_{3}$ と同形) お よび $\mathrm{SrMn}_{3} \mathrm{O}_{x} \quad\left(x=5.6 \sim 6.0\right.$, 構造未詳) が生成し, $1300^{\circ} \mathrm{C}$ 付

$*_{1}$ この報文を「マンカンンの複酸化物に関する研究（第 2 報）」 とする.

*2 前報（第 1 報）, 水谷惟恭, 北沢章生, 大郎信行, 加藤誠 軌, 工化, 73, 1097 (1970).

*3 Nobuyasu Mizutani, Nobuyuki ŌKuma, Akio KitaZAWA, Masanori KATO 東京工業大学工学部無機材料工 学科：東京都目黒区大岡山。

1）水谷, 北沢, 大隈, 加藤, 工化, 73, 1097 (1970)
近のせまい温度域では $\mathrm{Sr}_{4} \mathrm{Mn}_{3} \mathrm{O}_{10}$ (構造未詳) が生成する。1500 ${ }^{\circ} \mathrm{C}$ 以上の高温度域では $\beta-\mathrm{Sr}_{2} \mathrm{MnO}_{4}$ (正方晶系, $\mathrm{K}_{2} \mathrm{NiF}_{4}$ と同形), $\mathrm{Sr}_{3} \mathrm{Mn}_{2} \mathrm{O}_{7}$ (正方晶系, $\mathrm{Sr}_{3} \mathrm{Ti}_{2} \mathrm{O}_{7}$ と同形)および $\beta-\mathrm{SrMnO}_{3}$ (立方 晶系, ペロブスカイト構造)が生成することを報告し, $\gamma-\mathrm{SrMnO}_{3}$ (六方晶系, 高温型 $\mathrm{BaTiO}_{3}$ と同形), ブラウンミラライト構造の $\mathrm{SrMnO}_{2.5}$ および相当量の酸素欠宿を有する $\beta-\mathrm{SrMnO}_{3-\delta}$ の生成 することについても触れた。

$\gamma-\mathrm{SrMnO}_{3}$ については, Syono $5^{2)}$ は高温高圧 $\left(850 \sim 1300^{\circ} \mathrm{C}\right.$, 5 万気圧) 下で $\alpha-\mathrm{SrMnO}_{3}$ がこの構造 (Syono らは $\mathrm{SrMnO}_{3}$ (II) と呼称）に転移することを報告している。 $\beta-\mathrm{SrMnO}_{3}$ については 同じ論文中で 10 万気圧以上の超高圧下でなければ生成しないで あろうと予想している。

酸化物や複酸化物のなかには非化学量論的組成を持つ化合物の 存在することが知られている3)。たとえば酸化チタン $\left(\mathrm{TiO}_{x}\right)$ や 酸化バナジウム $\left(\mathrm{VO}_{x}\right)$ では生成条件によって化合物中の酸素含 有量が広く変化する。複酸化物や酸素酸塩ではタングステンブロ ンズ $\left(\mathrm{Na}_{x} \mathrm{WO}_{4}\right)$ のように陽イオンの含有量が変化する場合や, ペロブスカイト構造やその類似構造を持つ複酸化物, たと觉ば, $\mathrm{BaFeO}_{3-\delta}, \mathrm{SrFeO}_{3-\delta}, \mathrm{BaNiO}_{3-\delta}, \mathrm{CaMnO}_{3-\delta}$ などでは酸素欠損型

2) Y.Syono, S.Akimoto, J. Phys. Soc. Japan, 26, 993 (1969).

3）小泉, 新, セラミックス, 2, 34 (1967), 